Research note

\title{
Regulating Crisis: A Retrospective Ethnography of the 1982 Latin American Debt Crisis at the New York Federal Reserve Bank
}

\author{
Julia Elyachar
}

\begin{abstract}
Since the financial crisis of 2008, the term "crisis" has proliferated as a folk concept, and yet remained largely unexamined as an analytic concept. In this essay, I draw on my experience as a research assistant and research analyst at the Federal Reserve Bank of New York, during what would come to be called the Latin American debt crisis, to contribute to rethinking of financial crisis. Putting aside the assumption that we know a priori the meaning of crisis, I bring into view the material devices, temporalities and, in the words of Bronislaw Malinowski, the "imponderabilia of daily life" entailed by perceiving and regulating crisis. Rather than high-level officials of the Federal Reserve Bank, the essay focuses on research assistants, junior economists, midlevel officials, and also mainframe computers with their glitches and bugs. The essay shows how local, historically specific processes of generating knowledge in a 1980s office of the Federal Reserve Bank were part of grand projects of social reinvention, in which even the lowliest research assistant helped shape a narrative of crisis.
\end{abstract}

Key words: crisis; finance; regulation; Federal Reserve; ethnography; Latin American Debt Crisis

In her book Anti-Crisis, Janet Roitman demonstrates how much we have come to rely on the term "crisis" to make sense of the world (Roitman 2013). Crisis is intimately linked with valuation-or better yet, revaluation. It usually refers to a moment of rupture, an event in

Julia Elyachar, Department of Anthropology, University of California, Irvine, United States of America, elyachar@uci.edu

(C) 2013 Julia Elyachar

LiU Electronic Press, DOI 10.3384/vs.2001-5992.1312147

http://valuationstudies.liu.se 


\section{Valuation Studies}

which "true" value emerges from the shrouds of false, speculative value (Roitman 2013). Such a view has become increasingly untenable. From an exceptional event, crisis became part of the "new normal" (el-Erian 2008). It proliferates as a folk concept, but remains in the background unexamined as an analytic concept, due to its foundational place in Western thought (Roitman 2013). How, in fact, do we know that we are in a crisis? More specifically, how do financial regulators perceive crisis and what does it mean to regulate crisis? ${ }^{1}$ In this essay, I reflect on these questions by drawing on my experience as a research assistant and research analyst at the Federal Reserve Bank of New York, during what would come to be known as the Latin American Debt Crisis. It could be called a memoir, in that it refers to a time past that I am remembering now, but for reasons I explain below, I call it a retrospective ethnography (Maurer 2012).

\section{Memoir of a Research Assistant}

I was majoring in economics at Barnard College in 1982 when I went to work at the Federal Reserve Bank of New York. I put on stockings, carried a briefcase, and entered the world of bank regulation. I lived in downtown Manhattan at the time and walked to work through Soho - which was still an artists' postindustrial neighborhood-and on to the financial district, which is now a high-end residential neighborhood but then was completely empty after 5:00 p.m. That New York is gone. From my lowly vantage point at the Fed, I saw a particular era of finance disappear as well. Today, we know that 1982 marked the beginning of the end of Glass-Steagall, and the beginning of what many consider an era of speculative finance. ${ }^{2}$ It was the beginning of the end of a strange certainty, documented by scholarship (Chinn and Frieden 2011; Frieden 1987; Reinhart and Rogoff 2009) and commonly accepted among my peers, that loans to sovereigns from money center banks would be, unlike direct foreign investment, risk-free.

Thirty years later, all this seems impossibly long ago. My time at the Fed seems like a "deep history" of financial crisis (Shryock and Smail 2012) in which methods of critical financial studies do not apply. At the same time, as anthropologist Douglas Holmes has noted, I could walk into the NY Fed today and find pretty much the same

1 For ethnographies of financial regulation and regulators, see Holmes (2013), Miyazaki (2012), and Riles (2010) and for analysis by a financial journalist trained as an anthropologist, see Tett (2009).

2 The Glass-Steagall Act, or the Banking Act of 1933, separated commercial from investment banking and created the FDIC, or Federal Deposit Insurance Corporation. Many observers see the repeal of Glass-Steagall, as it is usually called in the United States, as a first step leading to the financial crisis of 2008. 
atmosphere, if better computers (Holmes, email communication 2012). One financial "crisis" has tumbled into another ever since.

My claim to fame as a bank regulator is small. Of a key speech given by former Federal Reserve chairman Paul Volcker to Congress about the debt crisis in 1982, I wrote two sentences. ${ }^{3}$ Those sentences were originally part of a memo I wrote for my manager and her superiors at the NY Fed. The memo made its way up levels of the institutional bureaucracy of the NY Fed, and then the Federal Reserve Bank, in numerous revisions and incorporations with other memos. I took part in other research projects concerning the elimination of Glass-Steagall, the rise of options, and the rise of what was then called "computerized banking," ATMs, and smartcards. After the 2008 financial crisis, I became fascinated by the way I kept hearing about the 1982 Latin American Debt Crisis. It floated in the air, as a faraway starting point for the financial crisis of 2008. I read nothing that conveyed a sense of what it was like to live through that crisis in situ, from an ethnographic perspective. Since there was no such thing as the anthropology of finance in 1982, and thus no ethnographic data about finance from that decade, it seemed a worthwhile exercise to return to my memories, notes, and writings of the time. There I found recorded some of the "imponderabilia of everyday life," to use Bronislaw Malinowski's classic term, that ethnography is so good at capturing and which can help open up that black box of "crisis."

\section{On the Street and in the Fed}

Working at the Fed was my first ethnographic experience, though I didn't have that training or conceptual language at the time. Much of what stays with me is the sensory experience of the Fed and NYC at the beginning of the 1980s. As a native New Yorker, I lived the financial revolution through changes on the streets of downtown New York as well. I started working at the Fed while finishing up my BA in economics and figuring out what to do next. A friend had suggested working at the Fed. So one day I walked from home to the Fed, with my resume in my hand. The employment office arranged an immediate

\footnotetext{
3 The testimony is mentioned in a fascinating interview with Paul Volcker conducted by PBS (Public Broadcasting Service) in 2000. One section of the interview discusses the lessons learned from the Latin American Debt Crisis: "The lasting impact was disappointingly little in one respect: We went from that crisis into some other banking crises around the world. The banks didn't exactly repeat the experience of Latin America, but they repeated a very similar experience elsewhere" (PBS 2000). Volcker also makes the interesting comment that the sense of crisis at the time pushed Mexico away from its protectionist policies and into NAFTA (the North American Free Trade Agreement): "the sense of crisis and the actuality of crisis pushed those countries away from their old controlled import substitution, isolation policies [and] into the world. It could have gone the other way, but it didn't." (PBS 2000)
} 


\section{Valuation Studies}

interview with one of the economists and a manager of a research department. Half an hour later, walking in the door at home, I found the phone ringing with a job offer.

The NY Fed is housed in a massive squat stone building built as the fortress it is: an important part of the US gold reserves are stored there. Many floors of the main Fed building are underground. This was long before September 11, 2001. Once you flashed an ID, you could walk right in. There was no metal detector. The Fed still allowed public tours in the old building that included viewings of the gold reserves. Every day I would pass by the lines of tourists waiting to go in. Like a typical New Yorker, I never made the time to go on the tour. You could walk freely anywhere in the Financial District in those days, right up to the stairs of the Stock Exchange or anywhere else in the neighborhood. That remained true until after September 11.

I worked across the street, on Maiden Lane. My office was on the $33^{\text {rd }}$ floor. As I approached the building, I would take my ID from my bag, and put it around my neck, flash it at the guard, and go up to my floor. Turning right from the elevators, I would enjoy the view out expansive windows facing south to the southern tip of Manhattan. Two small rooms to the left housed terminals for the mainframe computer. We would walk, paper in hand, to that room whenever we had to write or run code for our economists. One full-time computer programmer worked in there, on staff for the department. At the other end of the floor were the offices of the department manager, who had a $\mathrm{PhD}$ in economics, and her counterpart, who was a career bureaucrat at the Fed. Secretaries had their desks right outside the offices of the bank officers for whom they worked. One secretary was shared among three economists. There was a clear ethnic division of labor: The secretaries were African-American or Latina, except for the manager's secretary, who was white. The full-time programmer was from the Philippines. Economists and research assistants were white: half female and half male.

The organization of space reflected this hierarchy. Secretaries worked in open space. They had pictures of their kids on the walls, and neat, organized desks. Research assistants and research analysts worked in cubicles in the middle of the floor, with a modicum of privacy. No one had children: on the walls of the cubicles were postcards from friends, artwork, or nothing at all. The economists had their own offices with closed doors. But unlike the walls of the managers' offices, the walls of the economists' offices, facing the center of the room, were made of glass.

We research assistants were recent graduates from college with BAs, mainly but not only in economics. Many of us had gone to Ivy League schools, but not all; training programs at the investment banks paid more and attracted many of the Ivy League job candidates to the kind of training programs in investment banks studied 
ethnographically by Karen Ho ten years later (2009). That was the case even before the financial boom of the 1990s. My first weeks at the Fed were spent taking in-house training courses in finance, accounting, and computer programming. I learned to program in the Fed's proprietary computer language. The instructor taught us more than programming. When we were working on deadline and needed to produce data in tense situations, he told us repeatedly that we needed to stay calm, focus, and slow down. When you are in a hurry, slow down! In my first months at the Fed, we were never in a hurry. But I would use those lessons he taught us when crisis hit.

\section{Making Knowledge, Numbers, and Policy at the Fed}

My department conducted research on issues related to domestic banking regulation. International bank regulation was studied elsewhere. This division of knowledge reflected an assumption that domestic and international finance could be separated-which the Latin American Debt Crisis showed was untenable. When I started work, my department was a relative backwater. Economists found freedom in this status. Each research assistant worked for one or two economists.

I was originally hired to work for an economist focusing on risk. His research seemed very theoretical to me at the time. My job felt like an extension of school. I read articles related to his topic, asked lots of questions, and wrote simple computer programs for empirical tests of his theories. Things that took me a day or two of work to program could today be calculated in an instant. Another economist in our department was working on derivatives. I didn't work for her but struggled to understand what she was doing. Her research seemed incredibly abstract to me. And yet, it was central to issues that would go mainstream in the 1990s and 2000s. She was among those starting to think systematically about regulating the derivatives industry and how to integrate derivatives into the overall system of bank regulation. ${ }^{4}$ I talked sometimes to other economists at the Fed as well. Until Mexico threatened default, life in our department was slow. We worked regular hours. We could leave early if we had an appointment. We reported, normally, only to "our" economist. Chinatown was a few blocks away. Sometimes I would meet a friend there for lunch. We had time to chat in each other's offices. I felt peripheral to the primary work of the Fed, which to me seemed to go on across the street in the main building.

\footnotetext{
${ }^{4}$ For a fascinating account of regulation (and non-regulation) of derivatives, see Tett
} (2009). 


\section{Valuation Studies}

\section{Foreign Exchange at Night}

My friends Ed and John worked in Foreign Exchange across the street in the basement of the main building of the Fed. It was dark and had none of the niceties of our floor. We had met at training programs the first weeks of my employment. Where they worked, there were no secretaries, no pictures of kids, and no views. The mood of a guys' dorm room prevailed. Ed and John were computer geeks. They worked on their own, for all I could see. I never saw a supervisor in their office-although I knew that they had to produce data quickly and on deadline. They managed programs that charted currency transfers between the US and other countries. They worked on terminals of the Fed's mainframe computers. The computer was slow during the day. So they would come in around noon, and stay late at night, when the Fed's mainframe computers were faster. Their schedules were oriented around the downtime of the mainframe rather than the strictures of bureaucratic order.

At the end of my working day, we would order pizza, and sit around for hours as Ed and John worked. They would sit on their chairs by their terminals, waiting out response time from their input into the computers, which got faster as the evening wore on. I would shake off my high heels, move out of formal office mode, and watch as they input data and messed around with programs to try to get the balance of payments right. I had come out of my BA studies in economics, political economy, and finance thinking of foreign exchange balances as "real"-as reflecting underlying values in a transparent fashion. But some days the computers would fail, bugs in the programs would crop up, and those solid numbers about the US and its foreign exchange accounts began to look like a fiction. This was really dislocating for me.

Behind the apparently monolithic "Federal Reserve Bank," as I had thought of it, were a bunch of kids and of older guys waiting for retirement stumbling their way through crashes, mess-ups, and yet somehow getting through. There was always a program crashing, data lost, an emergency to be fixed, a moment in which that lesson of our computer teacher-to slow down when in a hurry-would be put to good use. In this sense, "crisis" was an everyday experience at the Fed across the street. It came to seem amazing to me that anything functioned at all; the image I had held of "The Central Bank" started to seem a façade. I had my first ethnographic experience of bureaucracy and the state. 


\section{Remembering Crisis}

How do we know when crisis has begun? For me, the Latin American debt crisis began with the clicking of my manager's heels down the length of the open floor of our department, a memo in her hand. Her steps were faster than usual, the sound of her heels sharper. The Latin American banking crisis had been brewing for a while across the street at the main building of the Fed, as something that was "international" in character. That day, it migrated over to the "domestic" side of the bank. I was standing with some colleagues leaning on the back of a cubicle, chatting about something or other. Joan said that she needed someone to help her run data regarding Mexico and bank exposure. I jumped at the chance to help and offered to stay late to do so.

Unlike my colleagues, I knew this issue was important. My knowledge was not from my training in economics, as good and as heterodox as that had been. Rather, my intuition grew out of my involvement with left politics in NYC, including solidarity movements with Latin America, and from my engagement in the NY Marxist School (later the Brecht Forum). It was there that I met and listened to Cheryl Payer, who wrote the prescient book The Debt Trap (Payer 1974). I followed the Spanish language news closely. I had access to a clearer picture of what was going on in Latin America before it erupted into financial crisis impacting on the United States as well. In the years before NGOs performed the task of rendering tacit and internal knowledge accessible to outsiders and policy makers the world round, the left inadvertently served as a transmission channel for reliable analysis of politics and political economy (including finance) that was useful for many players besides the solidarity movement.

As a manager, Joan did not have her "own" research assistant. She managed the economists. Only through them did she have contact with research assistants. But in this moment of crisis, the ordinary chain of authority broke down. And the crisis showed faults in many of our models, assumptions, and categories of data. Data were not in place to test the implications for the US banking system of a default on sovereign debt in Latin America. It was not an issue of concern. To fix the gaps in knowledge, the manual labor of a research assistant was needed.

My first task was to write a simple computer program to show the impact on the large money center banks' capital if Mexico defaulted on its interest payments. I decided to write up a memo interpreting my findings and their implications as well. In the early 1980s, all bank data was input by hand and stored in the Fed's mainframe computer. Code had to be written to look at different possible scenarios of default. Over the next few days, I ran a few other scenarios, including the possibility of default on principal payments as well as payments on interest, and what would happen if there were contagion and other 


\section{Valuation Studies}

countries defaulted as well. (Of course, work that took me a whole day would today be carried out in moments.) I mapped out exposure of the money center banks to various Latin American countries.

At an early stage of the crisis, I regularly went through printouts of confidential bank data available to the Fed regarding the exposure levels of individual money center banks to sovereign country debt (and total exposure) in various Latin American countries. I would then calculate how much of the sums that banks had counted as bank capital was in fact potentially bad debt exposure to Mexico and other Latin American countries. Data for the exposure of individual banks was given to me as printed pages with the words "highly confidential" on top. More macro data about banks were rated at an intermediate level of secrecy. I would keep these papers in a drawer in my desk in my cubicle. Some of the data I would input by hand into the programs I wrote to try to get a better picture of actual bank capital in the large money center banks. In short, I conducted a one-person stress test on the money center banks.

Help in the programming came from one of the department's programmers, a Filipino woman with a BA in computer science who wore very high heels and lots of makeup, and who was very sharp and efficient. Her closest friend was my manager's secretary. They shopped together at Filene's Basement on Chambers Street during lunch hour and solved all of our computer or technical problems with ease.

I began to research memos on different aspects of the debt crisis and its regulatory implications. For one memo, I researched and summarized the range of possible legal and regulatory responses to the bank crisis for the Fed. I wrote some others that I do not recall. I do remember researching various approaches to the regulation of sovereign debt, and different approaches to calculating bank capital. By that time, I was working for my manager full time.

Joan had been drawn into the highest levels of discussion at the NY Fed and the Federal Reserve about how to deal with the crisis. On our floor, this was reflected in a changed pace and patterning of physical movement around the floor. Before the crisis people walked slowly and regularly stopped to chat. That changed. People moved more quickly. Joan began to disappear across the street for long periods of time. The door to her office or the conference room would close more often. As a research assistant, I was not part of those meetings. But the memos I wrote, and the data I generated, made their way across the table to her peers in her office and across the street to higher levels of the NY Fed and the Federal Reserve. 


\section{Outcomes of the Crisis}

According to Paul Volcker, outcomes of the Latin American Debt Crisis were limited. History repeated itself all too soon (PBS 2000). Outcomes within our department were more prosaic. I was promoted to Research Analyst. My manager left for a promotion. Life on our floor became boring, even as our work had gained prestige. Work slowed down. I missed crisis. My cohort would all soon depart for the next adventure: MBAs for some, PhDs for others. None of us would be career employees at the Fed. I don't know what happened with the geek workarounds in foreign exchange that my friends had engaged in to deal with regular bugs in programs and other mishaps. But I could not help but think of them as the LIBOR (London Interbank Offered Rate) scandal erupted in the summer of 2012. Explanations of how it all started with some data mismatches made sense to me.

Toward the end of my tenure, a senior colleague told me of the Brady Plan that "solved" the Latin American Debt Crisis in 1982. This entailed a creative innovation: securitizing bad sovereign debt. Such an outcome was shocking to me. It seemed a scam or a joke. Within the organization, this innovation spurred research, and further use of this new regulatory instrument. By 2012, the notion of securitizing sovereign debt had been normalized. Regulatory workarounds in 1982 were but part of a toolkit in 2012 to deal with the EU debt crisis.

The research I took part in concerning new models of risk in banking and finance was also important in crises to come over the next 30 years. This was certainly the case with our research on GlassSteagall and its elimination. Neoliberal think tanks were pushing at the time for the deregulation of the Savings and Loan industry and the elimination of Glass-Steagall. I knew nothing about this. Who in the world would consider overturning Glass-Steagall? While the notion was pure theory, as one of our economists said when I asked him about why he was working on such an idea, we had to explore it. Of course, articles on elimination of Glass-Steagall were being published at the time by the Cato Institute journal, Regulation: The Cato Review of Business and Government, but I knew nothing about them. The Fed first began to pull back some of the provisions of Glass-Steagall in the mid-1980s, soon after I left the Fed. Our input into memos for managers and vice-presidents of the Federal Reserve helped create scientific legitimacy for the radical proposals being advanced to rewrite 


\section{Valuation Studies}

the nature of finance and the broader political economy of the United States and the globe. ${ }^{5}$

The data and memos we had created flowed into a longer-term process of knowledge making and regulating crisis at the Fed. Our workarounds were part of a broader process of revaluation that included technical issues of how to measure, track, and regulate bank capital. Raw data about sovereign debt loans (and all other categories of loans) had been available at the time of the Latin American Debt Crisis. But that data had not entered into the models we had in domestic bank regulation for calculating the adequacy of bank capital. Prevalent categories of data had not allowed the Fed to "know" that the debt crisis was coming, or that bank capital might be inadequate. This is why I spent so much time pulling out individual bank exposure data concerning Latin American sovereign debt, revising estimations of bank capital by hand, and running a one-person stress test of the major money center banks in the face of apparently imminent Mexican default.

In his interview with PBS in 2000, Paul Volcker notes that he had become concerned about levels of borrowing by Mexico some time before the crisis erupted (PBS 2000). His concern at that point was based on anecdotal evidence of a kind that resembles ethnographic, on-the-ground knowledge (Holmes 2013). Volcker's "sense" that something was off did not immediately move the bureaucracy to change its categories of data or assign research assistants to special research projects. It took "crisis" for that reorientation of categories and data to begin. Crisis is here not a sign of a falling rate of profit, or a slowdown in turnover time. It is not a decisive point of failure of a system and movement towards its transformation. Rather, crisis marks a moment when an ethnographic "sense" of things translates into an obvious seizing up of financial infrastructure. New forms of knowledge and data are sought out and brought to the fore due to the perceived seriousness of the situation. Crisis initiates a process of revision of models and data. Regulators had to study, like ethnographers, emergent realities for which no models existed.

\footnotetext{
5 PBS's The Wall Street Fix puts the changes of the period as follows: "In December 1986, the Federal Reserve Board, which has regulatory jurisdiction over banking, reinterprets Section 20 of the Glass-Steagall Act, which bars commercial banks from being 'engaged principally' in securities business, deciding that banks can have up to 5 percent of gross revenues from investment banking business. The Fed Board then permits Bankers Trust, a commercial bank, to engage in certain commercial paper (unsecured, short-term credit) transactions. In the Bankers Trust decision, the Board concludes that the phrase 'engaged principally' in Section 20 allows banks to do a small amount of underwriting, so long as it does not become a large portion of revenue. This is the first time the Fed reinterprets Section 20 to allow some previously prohibited activities." (PBS 2003).
} 


\section{Revisiting Crisis}

I have called this essay a retrospective ethnography. What might that mean? When I first drafted this essay in 2007, before the outbreak of what would become the 2008 Financial Crisis (with capital letters), I had in mind my positionality at the Fed. I conducted my work like a participant observer, gleaning out broader meanings from the imponderabilia of everyday life in the manner of classical ethnography. As such, when I returned to my archive of crisis, it was like returning to fieldnotes. But the notion of retrospective ethnography has further purchase, as noted by Bill Maurer when he suggests that we think of regulation itself as retrospective ethnography, a process through which "regulators format future action by resting on snapshots of previous modes of practice" (Maurer 2012, 303, fn. 9). The looping knowledge effect of regulation was explicitly on display with Timothy Geithner, former Secretary of the Treasury, and Ben Bernanke, former Chairman of the Federal Reserve, in the 2008 Financial Crisis: both were students of the history of financial regulation and brought their studies of the Great Depression (and of 1982) to bear on their approach to 2008.

But what of the end of Glass-Steagall, which was also being systematically worked out during my time at the Fed? Can we call that an exercise of retrospective ethnography? This idea makes a lot of sense in reference to emergent phenomena about which I wrote memos for my department in the 1980s, such as the "computerization of money," smartcards, and unregulated Euromarkets. But looking back at our research on Glass-Steagall and its elimination, a different dynamic was at work. And here, other problems with how we think of financial crisis as an eruption become clear. Jane Guyer's notion of punctuated time (2008) offers a better temporality for considering financial crisis. As a young person, I had no idea of the extent to which resources, both ideological and financial, were being poured into the elimination of Glass-Steagall, stubbornly and persistently, over decades in which such a notion seemed insane or, in my own young person's voice, a "completely abstract" exercise to consider.

The end of Glass-Steagall was not the beginning of it all-of this post-2008 world in which we live. This time of financial regulation and crisis was indeed more punctuated. To understand the rhythm of that punctuation, we need to take into account a broader range of actors than appeared on the floor and in the back rooms of the Fed. Mainframe computers and their crunch times matter, but so does the persistent work of those funding research about eliminating GlassSteagall. As we let go of our addiction to crisis, we have to look beyond, as Hart and Ortiz recently put it, the critique of finance as well (forthcoming). For one thing, as Roitman teaches us, crisis is inextricably bound up with critique. In the backrooms of crisis, in the 


\section{Valuation Studies}

geek computer rooms, the programmers' desks, and the hallways resounding with the clicking heels of a manager's fast walk, we can better learn about forms of tacit knowledge and punctuated learning that are crucial to financial regulation (Elyachar 2012). We can simultaneously pay close attention to grand projects of social reinvention at work in those times. Here, we need to ask as well: what kind of work does finance do; where does it fit into the broader scheme of economy and society; what kind of projects will it help us build (Hart and Ortiz, forthcoming)? In what other work is crisis enmeshed? My students at a public university in California understood this all too well.

My graduate students at the University of California, Irvine, were fascinated by details to which I had given little thought. Material devices that to me were infrastructure, lying in the background of perception, were for them the main story. They found it odd to realize that I had worked on mainframe computers, coming in late at night to avoid lag time, walked from one room to another to input data into a computer terminal, walked memos down the hall, worked without email, programmed in obsolete languages, and taken all day to run simple calculations. This usefully interrupted our original assumption that we were talking about a shared terrain of "financial crisis."

My undergraduates in this public university were struck by different details. After 1982, the young people whose lives and futures were changed by the financial crisis lived in Mexico. For UC students at that time, problems of structural adjustment in the wake of financial crisis were abstract. By 2012, it was all too familiar. My students and their families were borrowing more money each year to pay for everrising tuition. They faced the terror of unemployment when they finished school and had no idea of how to repay their loans. The detail that struck them most in my story was that I had been offered a job after only one interview, a mere half hour after the fact. This notion made them speechless. This was the world for which they pinedthough they would not have linked its disappearance to the 1982 Latin American debt crisis or the end of Glass-Steagall.

As my programming teacher taught me back in 1982, when crisis speeds up temporality, we need to slow down, to pay close attention to the ways in which new categories of data emerge, infrastructures seize up, workarounds emerge, and new realities take root. Much of what we thought of then as fraud is now normalized practice. We need to notice what has become normalized and how that took place. Only then can we understand how finance and the lowliest research assistant are enmeshed in grand historical processes of social reinvention. 
Acknowledgements. For their comments on earlier versions of this essay, I thank Andrew Barry, Nathan Coben, Keith Hart, Douglas Holmes, Paul Kockelman, Sean Mallin, Tomaž Mastnak, Bill Maurer, George Marcus, Taylor Nelms, Janet Roitman, and Ruth Turner, as well as two anonymous reviewers for Valuation Studies, Karin Thoresson, and the editors, Claes-Fredrik Helgesson and Fabian Muniesa.

\section{References}

Chinn, Menzie, and Jeffry A. Frieden. 2011. Lost Decades: The Making of America's Debt Crisis and the Long Recovery. New York: Norton.

El-Erian, Mohamed. 2008. When Markets Collide: Investment Strategies for the Age of Global Economic Change. New York: McGraw-Hill.

Elyachar, Julia. 2012. "Before (and after) Neoliberalism: Tacit Knowledge, Secrets of the Trade, and the Public Sector in Egypt." Cultural Anthropology 27 (1): 76-96.

Frieden, Jeffry A. 1987. Banking on the World: The Politics of American International Finance. New York: Harper and Row.

Guyer, Jane. 2008. "Prophecy and the Near Future: Thoughts on Macroeconomic, Evangelical, and Punctuated Time." American Ethnologist 37 (3): 409-421.

Hart, Keith, and Horacio Ortiz. Forthcoming. "Money and Finance from Ethnography to World History." Annual Review of Anthropology.

Ho, Karen. 2009. Liquidated: An Ethnography of Wall Street. Durham, NC: Duke University Press.

Holmes, Douglas. 2013. Public Currency: Communicative Imperatives in Central Banks. Chicago: University of Chicago Press.

Maurer, Bill. 2012. "Regulation as Retrospective Ethnography: Mobile Money and the Arts of Cash." Banking and Finance Law Review 27 (2): 299-313.

Miyazaki, Hirokazu. 2012. Arbitraging Japan: Dreams of Capitalism at the End of Finance. Berkeley and Los Angeles: University of California Press.

Payer, Cheryl. 1974. The Debt Trap: The International Monetary Fund and the Third World. New York: Monthly Review Press.

PBS (Public Broadcasting Service). 2000. "Paul Volcker" in Commanding Heights: The Battle for the World Economy. Interview conducted September 26, 2000. Available online at: http://www.pbs.org/wgbh/ commandingheights/shared/pdf/int_paulvolcker.pdf.

PBS (Public Broadcasting Service). 2003. "The Long Demise of GlassSteagall” in The Wall Street Fix. Available online at: http://www.pbs.org/ wgbh/pages/frontline/shows/wallstreet/weill/demise.html.

Reinhart, Carmen M. and Kenneth Rogoff. 2009. This Time Is Different: Eight Centuries of Financial Folly. Princeton: Princeton University Press. 


\section{Valuation Studies}

Riles, Annelise. 2010. Collateral Knowledge: Legal Reasoning in Global Financial Markets. Chicago: University of Chicago Press.

Roitman, Janet. 2013. Anti-Crisis. Durham, NC: Duke University Press.

Shyrock, Andrew and Daniel Lord Small. 2012. Deep History: The Architecture of Past and Present. Berkeley and Los Angeles: University of California Press.

Tett, Gillian. 2009. Fools Gold: How the Bold Dream of a Small Tribe at J.P. Morgan Was Corrupted by Wall Street Greed and Unleashed a Catastrophe. New York: Free Press.

Julia Elyachar is an associate professor in the Department of Anthropology at the University of California, Irvine, where she is also director of the Center for Global Peace and Conflict Studies. Her research interests include anthropology of finance, economic anthropology, Middle Eastern Studies, social theory, and valuation. She is the author of Markets of Dispossession: Economic Development, NGOs, and the State in Cairo (Duke 2005), as well as numerous articles in academic journals. 